\title{
Jesus as healer in the Gospel of Matthew, part 1: Methodology
}

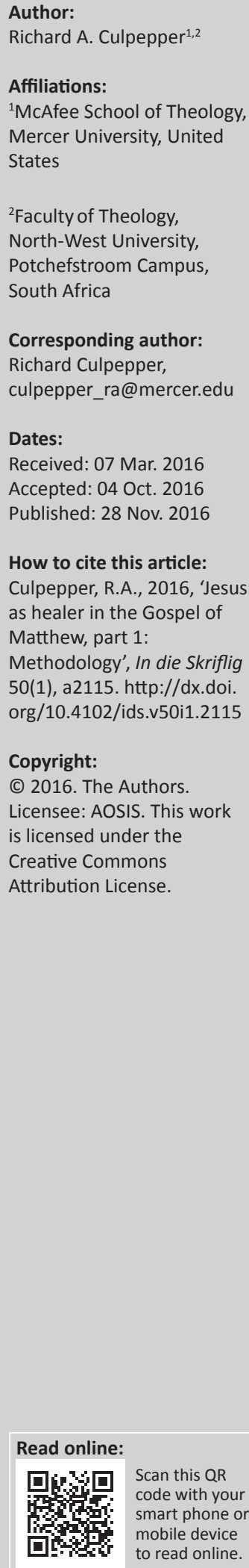

This exploration of the healing narratives in Matthew 8 and 9, guided by current scholarship in the fields of medical anthropology and social-scientific study of ancient Mediterranean culture, shows that when viewed in their historical and cultural context these biblical narratives point toward a more holistic understanding of healing that may encourage contemporary movements in this direction. In this context, the goal is 'healing' the person rather than simply 'curing' the disease. The goal of restoring persons to a state of well-being and social reintegration into their families and communities requires attention to the emotional, social, and spiritual well-being of persons as well as their physical health. A critically and culturally informed interpretation of Matthew's healing narratives may therefore promote the broader understanding of healing in view in these biblical stories.

The theme, 'New Testament and bioethics', ${ }^{1}$ is both noteworthy and unusual if for no other reason than because demands for specialisation mean that communication between healthcare professionals and biblical scholars seldom occurs. Some may naturally assume that it will be an exercise in simply lifting out from the New Testament ethical statements and principles that can be useful to doctors, patients, and medical professionals. These can be useful as they make decisions about courses of treatment, avenues of research, end of life procedures, and a host of other issues that lie within our grasp or on our frontiers. Such an approach to the topic, however, is much too narrow and overlooks the profound differences in the various ways healing is understood today and was understood in the ancient world. In actual fact, the challenge of drawing ethical guidance from the New Testament is so daunting that the temptation is to simply identify the challenges posed by our theme. I will resist this temptation, but it would be irresponsible to try to proceed without taking stock of these challenges.

The ampersand in our theme promises to bring together faith and science, sacred scripture and biomedicine. Doing so requires engaging the debate between faith and science both in our twentyfirst century context and in the ancient Jewish, Mediterranean, Hellenistic, and Roman cultures in which the New Testament was written. The clash of cultures and the suspicions raised on both sides of the science and faith dialectic are certainly not new; they predate the New Testament. Early in the 2nd century вс Jesus ben Sirach, a Jewish wisdom teacher embracing the authority of the Torah while facing the transformation of Jewish culture by the new wave of Hellenism, grudgingly advised his pupils to avail themselves of the healing arts of physicians, while at the same time warning them to seek God's healing help first. Listen to his ambivalence:

Honor physicians for their services,

for the Lord created them;

for their gift of healing comes from the Most High,

and they are rewarded by the king.

The skill of physicians makes them distinguished,

And in the presence of the great they are admired.

The Lord created medicines out of the earth,

And the sensible will not despise them.

My child, when you are ill, do not delay,

But pray to the Lord, and he will heal you.

Give up your faults and direct your hands rightly,

1.This article was originally presented as the first part of a two-part presentation at conferences held at the Faculty of Theology at NorthWest University and at Stellenbosch on 25 and 27 August 2015. Special thanks to Dean François Viljoen and Professor Jan G. van der Watt for organising these conferences. 
And cleanse your heart from all sin

Offer a sweet smelling sacrifice,

and a memorial portion of choice flour,

and pour oil on your offering, as much as you can afford.

Then give the physician his place, for the Lord created him;

do not let him leave you, for you need him.

There may come a time when recovery lies in the hands of physicians,

for they too pray to the Lord

that he may grant them success in diagnosis and in healing, for the sake of preserving life. (Sir 38:1-4, 9-14)

So here it is: Pray first, but go to a physician; recovery may lie in the physicians' hands, for they too pray. Sirach recognises both the ancient lore and contemporary medicine, the sacred and the professional, the importance of prayer, offerings, and cleansing your heart from sin on the one hand, and pharmaceutical science and medicines from the earth on the other. His bridge between the two is that God created both (cf. Kee 1986:19-21; 1992:660-661; Temkin 1991:89-90).

Views of the role of physicians and healers were in flux in the period of Second Temple Judaism (cf. Hogan 1992). The traditional view was that God sent illnesses as punishment for sin. Therefore one should repent and pray for healing (Kee 1986 12-16; Wilkinson 1998:54-56). Sirach takes a mediating position, retaining the traditional view, but making a place for physicians and herbalists. Philo and Jubilees (10:10-13) treat medical knowledge as part of the wisdom revealed to humans. Other Jewish writers of the period (1 Enoch) maintain the traditional view, leaving little place for physicians and healers. On the other hand, a 'medical report' found at Qumran that describes ailments and treatments of members of the community shows that Hellenistic medicine was known among the Essenes (Kee 1986:46-47). In Tobit the archangel Raphael becomes the healing angel. Consulting a physician only made Tobit's eye condition worse, but Raphael heals Tobit and instructs Tobias about how to use fish parts to chase away a demon. Rebecca Raphael concludes from these sources that ' 1 Enoch, Tobit, and Jubilees all prescribe a medical function to angelic intermediaries' (Raphael 2010:711).

In pursuit of our theme, I will propose an approach to the topic that draws on two areas of study, namely medical anthropology and narrative criticism. This article (Part 1) deals with the methodological approach to drawing implications for bioethics from the New Testament, and Part 2 reads the healing stories in Matthew 8-9 with an interest in their potential for bioethics.

\section{Jesus as healer in the light of medical anthropology}

The primary difficulty we encounter in interpreting Jesus' role as a healer is that the Gospels make use of 1st-century Hellenistic-Jewish language and concepts that would have been common to both their writers and their first audiences. We, however, read the Gospel accounts with 21st century assumptions and understandings that alternatively make us deaf to what the Gospels are saying or trap us into assuming that our science is better than their ancient medical folklore. The result in either case is that we are in no position to identify any meaningful principles for biomedical ethics.

Modern western medicine addresses diseases, i.e. biological and psychological disorders. The root causes are typically viral, bacterial, or genetic, and the cure involves proper diagnosis and prescription of the medications most effective in controlling or alleviating the disease or disorder. The entire basis for modern western medical practice, however, was unknown in antiquity - long before the invention of the microscope, probably in the Netherlands in the late 1590s. As Sirach illustrates, 1st-century understandings were far different. Even today the scientific understanding of diseases is alien to the culture and practice of perhaps $80 \%$ of the earth's population.

Responding to this disparity, studies of primitive medicine, mental health in diverse cultures, and international public health, especially after World War II, led to the development of Medical Anthropology as a subdiscipline of Anthropology (Foster \& Anderson 1978; Singer 1989:1193). Horacio Fabrega, Jr. (1971) defined a medical anthropological inquiry as one that:

(a) elucidates the factors, mechanism, and processes that play a role in or influence the way in which individuals and groups are affected by and respond to illness and disease, and (b) examines these problems with an emphasis on patterns of behavior. (p. 167)

Like any new academic discipline or field of inquiry, Medical Anthropology has experienced sharp debates between its clinical and its critical anthropologists, reflections on its shortcomings, distress over the 'medicalization of medical anthropology' (Morgan 1990; Singer 1998:1194)² and suggestions regarding its future development (e.g. Scheper-Hughes 1989; Scheper-Hughes \& Lock 1986; and Singer 1989; 1990).

Medical anthropologists have identified a set of concepts that shed light on the healing narratives in Matthew, although these results too have been subjected to criticism. ${ }^{3}$ Among these we will focus briefly on the distinctions between disease and illness, revised understandings of 'health', the social and political contexts in which illness and healing are experienced, and the role(s) of healers.

John Pilch, who led the way in introducing the insights of medical anthropology to New Testament scholarship, points

2.Scheper-Hughes (1989) cites Alan Harwood (personal communication) for the observation that 'an unanticipated side effects (sic) of the popularity of the 'disease/ illness' dichotomy is that it has created a single discourse for anthropologists and illness' dichotomy is that it has created a single discourse for anthropologists and well as healing for the biomedical domain' (p. 66).

3.See, e.g. Scheper-Hughes (1989): 'Critical medical anthropology has become a new coe, e.g. Scheper-Hughes (1989): 'Critical medical anthropology has become a new
commodity, carefully sanitized, nicely packaged, pleasant tasting (no bitter aftercommodity, carefully sanitized, nicely packaged, pleasant tasting (no bitter after-
taste) - the very latest and very possibly the most bourgeois product introduced into the medical education curriculum' (p. 66) 
out differences in understanding such basic concepts as health and sickness. Modern definitions are moving to a broader definition of health than 'freedom from disease or ailment'. In 1946 the World Health Organization adopted a more comprehensive definition, which is broader and more reflective of the concept of health in non-western societies: 'Health is a state of complete physical, mental and social well-being and not merely the absence of disease or infirmity'. ${ }^{4}$ Pilch (2000:24) claims that 'health is best understood as a condition of well-being as understood by a given culture'.

Illness as well as health and healing is culturally defined, and in ancient Mediterranean culture it included social devaluation, loss of place, detachment, and alienation (Malina \& Rohrbaugh 1992:71). The experience of illness, its symptoms or description, and the healing process are all understood in the context of a larger societal system. Furthermore it is a shared or collective understanding. The ill person, family and friends, and the healer all participate in this conceptual worldview by which they interpret both the illness and the work of the healer. Conceptual worldviews continue to condition the way we think about healing.

A major contribution of medical anthropology, particularly relevant for biblical studies, has been the way it has called attention to how cultural context shapes the way we think about the body, illness, and healing. In 1987 Nancy ScheperHughes and Margaret M. Lock challenged the hegemony of Cartesian dualism (mind or body) and its attendant assumptions of real or unreal, magical or rational:

A singular premise guiding Western science and clinical medicine (and one, we hasten to add, that is responsible for its awesome efficacy) is its commitment to a fundamental opposition between spirit and matter, mind and body, and (underlying this) real and unreal. (p. 8)

This dichotomy is not modern, however, but can be seen in Hippocrates' treatise on epilepsy, 'the sacred disease' as quoted by Scheper-Huges and Lock (1987):

I do not believe that the so-called Sacred Disease is any more divine or sacred than any other disease, but on the contrary, just as other diseases have a nature and a definite cause, so does this one, too .... It is my opinion that those who first called this disease sacred were the sort of people that we now call 'magi'. These magicians are vagabonds and charlatans, pretending to be holy and wise, and pretending to more knowledge than they have. (p. 9)

Challenging this construct, they (Scheper-Huges \& Lock 1987:6) begin instead with the understanding of the body 'as simultaneously a physical and symbolic artifact, as both naturally and culturally produced, and as securely anchored in a particular historical context', and invite consideration of the relations among 'three bodies': the individual body, the

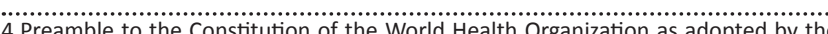
International Heath Confen of the Now 19-22 June 1946; signed on 22 July International Health Conference, New York, 19-22 June 1946; signed on 22 July 1946 by the representatives of 61 States (Official Records of the World Health Organization, no. 2, p. 100) and entered into force on 7 April 1948. The definition has not been amended since 1948 (http://www.who.int/about/mission/en) social body, and the body politic. Their analysis provides a model for understanding Jesus' role as a healer in the 1stcentury Jewish context. In contrast to modern biomedicine, non-western ethnomedical systems 'do not logically distinguish body, mind, and self, and therefore illness cannot be situated in mind or body alone' (1987:21). They (1987:10) note, however, that 'we lack precise vocabulary with which to deal with mind-body-society interactions' and hence we resort to fragmented concepts such as 'bio-social' and 'psycho-somatic'.

Cultures perceive the self or individual differently. In Japan, for example, the family is the fundamental unit of society, not the individual; and the Gahuku-Gama of New Guinea lack a concept of the person altogether (Scheper-Huges \& Lock 1987:14-15). In addition, various cultures have assigned special significance and often metaphorical functions to various organs, functions, or body fluids such as the liver (French, Spanish, Portuguese, and Brazilians), the bowels (English and Germans), blood (traditional Chinese and some black Americans). American midwestern farmers attach great significance to the backbone, and derivatively 'getting around', 'being upright', not 'stooping to anything', or being 'spineless' (1987:17-18, citing Strauss 1966:137 and Cobb 1958). The importance of purity for 1st-century Pharisees - cleansing and protecting oneself from defilement from contact with the body fluids of others, especially Samaritans and Gentiles - may also be viewed in this context.

Other aspects of the interactions between the individual, society, and 'the body politic' are similarly suggestive for interpreting Jesus' role as healer in Matthew. Scheper-Hughes and Lock explore further the patterns of response to threats to the social order in which both self-control and social control are intensified. Among villagers in rural Ireland, for example, they found that the villagers were guarded about being 'taken in' by outsiders, as they (1987) explain:

Concern with the penetration and violation of bodily exits, entrances, and boundaries extended to material symbols of the body - the home, with its doors, gates, fences, and stone boundaries, around which many protective rituals, prayers, and social customs served to create social distance and a sense of personal control and security. (pp. 24-25; citing Scheper-Hughes 1979)

Again biblical scholars can see the implications of such interactions between social and political threats for the increased preoccupation with protection against evil spirits, erosion of boundaries, and loss of control over the temple and the sacrifices offered there during the Second Temple period.

In one final example drawn from Scheper-Hughes and Lock (1987:28), biomedicine has often served the interests of the state with respect to the control of reproduction, sexuality, women, and sexual 'deviants'. Here these authors note the development in the 19th century of various disciplines related to the control of human (especially female) sexuality and the parallel development of ideologies of personal 
asceticism, sexual puritanism, and patriarchal households. The same, of course, can be seen in ancient Judaism with its patriarchal orientation, marriage contracts, and restrictions aimed at preventing or at least minimising contacts between men and women outside of the family.

These examples are sufficient to illustrate the value of studies in medical anthropology for biblical interpretation in general and Jesus' healings in particular. One other element drawn from medical anthropology needs to be defined, however, before one turns to the Gospel of Matthew, namely the role of the healer. Pilch (2000) called attention to the importance of explanatory models (Ems) of the functions of participants in the healing process:

Social scientists note that all people have multiple belief systems to which they turn when they need help [hear Sirach again!].

Ems are the notions about an episode of sickness and its treatment that are employed by everyone involved in the process (the sick person, family, friends, village, healers). These models are embedded in the larger cognitive systems that in turn are anchored in particular cultural and structural arrangements that is, the health care system sectors and sub-sectors.

While it is the whole system and not just the healer that heals, the transactions between sick people and healers are critical ... What takes place in the interaction is interpretation of symbols and signs in terms of very particular interpretive schema.

The diverse Ems that all the actors in a healing transaction bring to the event influence the interactions and interpretations that take place. The sick person and the healer are best understood as engaging in the interpretation of the context of the encounter, which itself is symbolic, and of the symbolic forms that are manipulated by the other during the encounter. (pp. 29, 30)

Practitioner and patient participate in a cultural conceptual system or explanatory model whether the healing is ascribed to modern medicine, faith and prayer, or the practice of meditation (cf. Fiffer 2014; Keener 2010). Symbols are manipulated in the encounter between healer and patient, and patients experience a return to health.

Walter Wilson (2014:28-29) has refined Pilch's model of three sectors - the professional, the popular, and the folk - noting that healers can be official or unofficial and they can operate with supernatural or natural assumptions, resulting in four sectors (see Table 1).

Cultic healers were priests in temples or cultic centers of gods associated with healing (Asclepius and Isis) who could lead pilgrims seeking healing in the sacred rites. A 4th century ce inscription contains a list of healings attributed to the priests of Epidaurus (see Boring et al. 1995:64). In antiquity professional healers, the smallest of the four sectors, were generally those who had been trained in one of the Hippocratic schools and

TABLE 1: Model of the cultic, professional, popular and folk sectors.

\begin{tabular}{lll}
\hline Variable & Supernatural & Natural \\
\hline Official & Cultic & Professional \\
Unofficial & Charismatic & Folk \\
\hline
\end{tabular}

Source: Wilson, W.T., 2014, Healing in the Gospel of Matthew: Reflections on method and ministry, Fortress, Minneapolis more often sought natural causes and therapies - and expected remuneration for their services (Temkin 1991: 10-13). Most sick people would have relied on folk healers, often family members administering traditional folk remedies with a dose of superstition. Charismatic healers were distinguished primarily by their personal powers and access to spiritual or magic means of healing, which John Meier (1994:549) describes as 'manipulation of various (often impersonal) supernatural forces or the coercion of a deity in order to obtain a desired concrete benefit'. Because Jesus would have been identified with this sector, we may explore it in somewhat more detail. Apollonius of Tyana and Hanina ben Dosa are often cited as examples of other charismatic healers from antiquity. Mishnah Berakot, the tractate on prayer, records the following famous description of Hanina's healing:

It is told concerning Rabbi Hanina ben Dosa that when he prayed for the sick he used to say: This one will live and this one will die. They said to him: How do you know? He replied: If my prayer is fluent in my mouth, I know that he [the sick person] is favored; if not, I know that [his illness] is fatal. (m. Ber. 5:5; Danby 1933:6)

Meier's assessment of these traditions shows firstly that the sources that record them are not contemporary with Apollonius or Hanina, and secondly, in the case of Hanina (as with Honi the circler drawer) the wonder is the power of their prayer, or Hanina's foreknowledge of his prayer's efficacy, rather than his miracle working. Care must be taken, therefore, in the claims made for these and other ancient healers (cf. Meier 1994:576-601). Furthermore, after listing characteristics of the miracle stories in the Gospels and comparing them with the Greek magical papyri, Meier (1994) concludes that:

there is an objective basis for designating Jesus' supposed wonders 'miracles' instead of 'magic', even though in a few cases magical traits may enter into some of the miracle stories. (p. 550)

Finally one must give at least a passing nod to the question of historicity. On what basis can the claim be made that the healing miracles ascribed to Jesus are any more credible than those attributed to other ancient healers? Firstly, Meier (1994:3) cites the probative argument of Morton Smith that 'without his miracles, Jesus would never have attracted both the enthusiasm and the opposition that marked and finally ended his public life'. The gospels present Jesus not just as a prophet and teacher but as one whose activities gained for him a reputation as a healer and wonder worker. The Church Fathers also spoke of Jesus as a physician (Wilkinson 1998:63, cites Ignatius of Antioch, Ephesians 7.2; Clement of Alexandria, Paedagogus I: 1.1; 2.6; 6.36; 8.64; and 12.10; Origen, Contra Celsum 2.67; Origen, Homily on Leviticus 8.1; Eusebius, Ecclesiastical History 10.4.11). Even if these reports have been exaggerated or embellished over time, Jesus' healings and exorcisms were integral to his announcement of the kingdom of God (cf. Culpepper 2013a:78-79). Marcus Borg (Borg \& Wright 1999) agrees:

Behind this picture of Jesus as healer and exorcist, I affirm a historical core. In common with the majority of contemporary 
Jesus scholars, I see the claim that Jesus performed paranormal healings and exorcisms as history remembered. Indeed, more healing stories are told about Jesus than about any other figure in the Jewish tradition. He must have been a remarkable healer. (p. 66)

With this brief excursion into the literature of medical anthropology and social-scientific study of ancient Mediterranean culture in place one may turn to narrative criticism, the cultural construction of healing narratives, and implied ethics as tools for interpretation of the portrayal of Jesus as healer in the Gospel of Matthew, and especially in the miracle stories of Matthew 8-9.

\section{Jesus as healer in the Gospel narratives}

Above we considered the challenge we encounter in interpreting the gospels' 1st-century Hellenistic-Jewish language and concepts, especially as they relate to healing. Howard Clark Kee made the striking observation that 'there is in the gospels not a single instance of the technical language or methods of the medical tradition from the time of Hippocrates to Galen' (Kee 1986:65-66). The second difficulty we encounter in interpreting Jesus' role as a healer therefore lies in the nature of the Gospel accounts in general and the Gospel of Matthew in particular. The Gospels not only arise out of their time and culture, they record Jesus' work as a healer in the interest of announcing his identity as the Messiah of Israel and the Son of God.

In order to read the healing stories in Matthew 8-9 with an interest in what they may offer in terms of bio-medical ethics, our reading will be guided methodologically by narrative criticism, giving particular attention to the narrative's constructions of illness and healing, and the Gospel's implied ethics. A word of explanation about each is therefore in order.

\section{Narrative criticism}

Narrative criticism is based on literary theory rather than historical investigation (cf. Moore 1989; Powell 1990). It seeks to understand both the story that is told and the way it is told. Standard elements commanding the attention of narrative critics are the role of the narrator, plot, settings, characters and characterisation, symbolism, irony, and the construction and role of the implied reader. Characters play a particularly important role in the Gospels because they can concretise responses to Jesus' teachings, particular virtues or problems in discipleship, and offer models for responses readers may make. The implied reader is a construct, neither the real 1st-century readers nor real 21st century readers but the reader that is encoded in the narrative. Every written text implies a reader who can read the text, assumes what is assumed in the text, requires the explanations that are given, and is able to make the connections and inferences required by the text. For our present purposes we should simply note that the implied reader shares the Gospel's assumptions about illness and healing. The implied reader shares the author's conceptual world. What the text communicates is not new information about illness and demon possession, or healing and exorcism, but about Jesus' power to heal and the place of healing in his ministry and proclamation of the kingdom. Our role as readers is to play the role of the implied reader, enter into the narrative world of the Gospel, and hear the narrator's story about Jesus as fully as possible. What we can learn about the ancient world, Second-Temple Judaism, ancient Mediterranean society, and medical anthropology is important, therefore, because this information is assumed by both ancient authors and their intended and implied readers, and is encoded in the Gospel in various ways (cf. Allison 1993; Anderson 1994; Kingsbury 1986; and Talbert 2010).

\section{Narrative construction of illness and healing}

Narrative construction of illness and healing as an element of the interpretation of healing narratives may be traced to Susan Sontag's (1977:3) Illness as metaphor and AIDS and its metaphors, in which she defines her topic as 'the uses of illness as a figure or metaphor'. She points out how diseases acquire metaphorical or symbolic associations and calls for 'demythicising' such diseases as tuberculosis and cancer. In France and Italy, for example, at least at the time of her writing, it was the rule that doctors communicated a cancer diagnosis to the patient's family but not to the patient (1977:7), and in America major cancer hospitals mailed communication and bills in envelopes that did not reveal the sender (ibid:8). With the Romantics TB was regarded as a form of the 'disease of love'. Fever was a sign of 'inward burning', and sex was recommended to TB patients as a therapy (1977:20-21). Following this line of thought, interpretation of the healing accounts in Matthew needs to pay attention to the metaphorical significance of illnesses such as leprosy, blindness, and menstrual bleeding.

In 2000 Cheryl Mattingly and Linda C. Garro published a volume entitled Narrative and the cultural construction of illness and healing, a collection of essays that contributed to medical anthropology's turn toward narrative a decade after its advent in New Testament scholarship. The contributors to this volume examine the ways in which narratives of healing and their telling and hearing are culturally constructed. This relatively new area of study has direct bearing on the composition, reception, and interpretation of the healing narratives in the Gospel of Matthew. The introduction to this volume cites Bruner and Feldman's insight that the 'facts' of the past, by themselves, 'do not supply the patterning or schematic structure of narrative reports' (Mattingly \& Garro 2000:13-14, citing Bruner \& Feldman 1996:293). Such reports 'must be constructed of cultural material'. Young (1995; quoted by Mattingly and Garro 2000:14) found that 'while the content of the narrated accounts changes from case to case, the structure remains constant'. Speakers impute various meanings to their experience, and these meanings can change over time. The narratives, moreover, can influence subsequent actions of the narrator and the audience (Mattingly \& Garro 2000:15) and hence have ethical implications. They also convey 
insights into culturally constituted social relationships, for example who is entitled to tell a story, and when is it told? One interviewer reported that members of a well-to-do family in Turkey told the story of the illness of a daughter-inlaw while she remained silent (Good 1994:60; cited by Mattingly \& Garro 2000:15). Among Australian aborigines entitlement to tell the story reflects an enduring relationship based on the indebtedness incurred by the patient: 'The debt between patient and caring helper lasts for as long as they both shall live' (Sansom 1982:188; cited by Mattingly \& Garro 2000:19). Illness produces a significant disruption in one's life, so patients typically struggle to maintain a sense of self and purpose. The act of telling their story, giving it shape and meaning, and sharing it can be therapeutic in itself. The work of Mattingly and Garro and their collaborators opens new lines for inquiry into the cultural construction and functions of the Gospel healing narratives and their ethical implications, which leads us to another recent development in narrative studies.

\section{Implied ethics}

Implied ethics designates the values, norms, correctives, or ethics that may be inferred from the narrative text, whether it offers any explicit ethical instruction or not (see the groundbreaking work of Van der Watt \& Zimmermann 2012). It is therefore based on the communication model assumed and explored by narrative criticism. Just as the implied author may expect that the implied reader will grasp the meaning of symbols, irony, humor, or criticism conveyed implicitly by the text, so also the narrative contains assumed values and implicit ethics that may be communicated through the narrator's comments, what characters say and do, how other characters respond to them, and what happens to them. The relationship between the Gospel's themes and its characters is also significant (Culpepper 2013b). Readers of the Gospels are particularly justified in searching out their implied ethics because the Gospels present Jesus as a highly authoritative character (divine) who teaches and models his teaching for his followers, and therefore by implication for readers of the Gospel. The implied ethic of the Gospel of Matthew, I suggest, is mimetic. That is, Matthew presents Jesus as the Messiah and teacher to be obeyed and imitated by the church. The reader should learn from what Jesus does as well as what he says. The teachings of Jesus in Matthew 5-7 are followed by the collection of miracles in Matthew 8-9. Both serve the didactic functions of the Gospel.

In a coherent narrative like the Gospel of Matthew, one may expect that what is implied will be coherent with what is stated explicitly. In politically subversive literature and modern ironic novels, one finds examples of narratives which purport one thing explicitly but subtly contradict the explicit message through what is implied. That is not the case with Matthew; what is implied illustrates, supports, and reinforces what is stated. Janice Capel Anderson (1994:36) defines redundancy as the availability of information from more than one source'. Implicit communication is one form of redundancy in which various aspects of the narrative all contribute to the communication of the narrative's primary message or themes. Matthew's main themes include Jesus as the Christ (Messiah), Jesus as the new Moses, Jesus as teacher, and Jesus as agent of the kingdom. These themes are related but each highlights an important thread of Matthew's message. Because we may expect that the healing narratives in Matthew are related to Matthew's leading themes, a brief overview of Matthean themes follows.

\section{Matthean themes}

The narrator announces Jesus as the Christ $(1: 1,16,17), 5$ reports his birth as the birth of the Christ $(1: 18 ; 2: 4)$, and characterises his works as those of the Christ (11:2). Peter confesses Jesus as the Christ (16:16), and Jesus charges the disciples to tell no one that he is the Christ (16:20). Jesus asks the Sadducees whose son the Christ is (22:42), and instructs the crowds and his disciples to call no one teacher

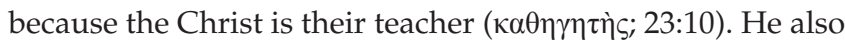
instructs them not to be misled when others claim to be the Christ $(24: 5,23)$. Jesus is then tried, mocked, and condemned as the Christ $(26: 63,68 ; 27: 17,22)$.

\section{Jesus as the new Moses}

Beginning with the birth narrative, Matthew wraps Jesus in 'the mantle of Moses' (Allison 1993). Like Moses, he will be the deliverer of his people (1:21), the king seeks his life and kills innocent children (2:7-12,16-18), and he (his family) flee from the king and then comes 'out of Egypt' (2:13-15). Later, Jesus goes up on a mountain and gives his followers a new teaching on righteousness that fulfills the law and the prophets' (5:17-20). Moses and Elijah appear with Jesus on the Mount of Transfiguration (17:3), but his teachings interpret, fulfill, and supersede the Law of Moses (19:7-8; 22:24). As F. Scott Spencer (2010:368) aptly put it, 'Above all, Matthew's Jesus emerges as the church's authoritative biblical exegete and teacher'. And in the end 'all authority' is given to him (28:18; see Culpepper 2015).

\section{Jesus as a teacher}

In Matthew, Jesus is regularly addressed and referred to as 'teacher', especially by the authorities and outsiders to the group of disciples $(8: 29 ; 9: 22 ; 12: 38 ; 17: 24 ; 19: 16 ; 22: 16,24,36)$. Jesus himself teaches about the role of a teacher (10:24-25), and refers to himself as teacher $(23: 8 ; 26: 18)$. Beyond these references, Matthew devotes a significant portion of the Gospel to reporting Jesus' teachings, including five (or six) major sections of discourse material. In the last verse of the Gospel, Jesus instructs his disciples to go and make other disciples 'teaching them to observe everything that I have commanded' (28:20).

\section{The kingdom of heaven}

The primary theme of Jesus' teachings is the kingdom of heaven, which occurs 24 times in Matthew. Like John the Baptist, Jesus' call is 'Repent, for the kingdom of heaven has come near' $(3: 2 ; 4: 17)$, and he sends his disciples out with the 5.References indicated with only a chapter and verse number come from Matthew. 
same proclamation (10:7). Jesus' parables typically convey an image or metaphor for the kingdom (13:24, 31, 33, 44, 45, 47, and 52). Those who are righteous will enter the kingdom, but true righteousness requires faithfulness, obedience, and works of compassion. Good trees bear good fruit (7:16-20). One who hears Jesus' teachings and acts on them is like a wise man (7:24). The faithful servant is at work when his master returns (24:45-51). Wise maidens are prepared (25:1-13). The worthless slave does nothing with the talent he is given (25:14-30), and the sheep and the goats are distinguished by whether they did acts of compassion for the 'the least of these' (25:31-46). These are the ethical norms of the kingdom.

\section{Implications for bioethics}

On the basis of our forays into medical anthropology, ancient Mediterranean culture, healing in Second Temple Judaism, narrative criticism, narrative constructions of illness and healing, implied ethics, and Matthew's leading themes, we can now begin to draw out implications for bioethics. The topics we have explored expose various layers of our subject. Part 2 of this article will identify other implications that are common to the Gospels and some that reflect the particular theology and character of Matthew. We can therefore group our observations, moving from the more widespread to the more particular. Since each succeeding level is a part of the previous, broader context, what is true of the broader context is generally also true of the more specific context. The implications discussed below are selective; others could be listed also, but these have been selected for their possible relevance to contemporary medical, ethical, and religious professions and communities. The implications listed below could also be developed much more fully. We will assume the foregoing explorations and merely reference them for illustrative purposes.

\section{Implications of medical anthropology and social- scientific study of ancient Mediterranean culture}

One of the main contributions of medical anthropology and social-scientific study has been to draw our attention to the cultural differences in the understanding of disease both now and in ancient Mediterranean culture. Illness is culturally defined, and it includes physical, social, and spiritual dimensions. Healing is also culturally defined and should therefore be understood more broadly than the typical, modern medical focus on curing a patient's disease.

In antiquity illness carried with it incapacity and displacement from family and community, and the attendant loss of personal worth. The goal of healing therefore was the full restoration of a person to a state of wellbeing and their place in their family and community. There are therefore social and relational aspects of healing that afford important opportunities for the collaboration of medical, health care, social, and religious professionals, religious communities, and the patient's family. As we have seen, however, there has been a tendency for medical practitioners to 'medicalize' the psychological and spiritual aspects of illness, raising questions of the limits of medicine and the need for collaboration between medical professionals and others who can respond to the psychological, social, and spiritual needs of patients. Scheper-Hughes (1989), for example, reports:

One thing I do not hear from my colleagues in medical anthropology but rather from within some quarters of clinical biomedicine is an invitation to reduce rather than expand the parameters of medical efficacy, a call for a more humble model of doctoring as 'plumbing', simple 'body-work' that would leave social ills and social healing to political activists, and psychological/spiritual ills and other forms of existential malaise to ethnomedical and spiritual healers. (p. 67)

Above we defined the various ancient healers and healthcare systems in a grid with four quadrants (sacred and secular, folk and professional). These typically functioned in relative isolation from one another, although a patient might well seek help from more than one kind of healer (see Sirach again). In each system, faith in the healer or in that healing system was important for its effectiveness in bringing healing. Whatever the system, patients needed or need to believe that it can address their needs. Where such faith is lacking, success in bringing healing is reduced. Establishing effective professional collaboration among professionals in various fields continues to be one of the challenges for the helping and healing professions.

\section{Implications of views of healing in ancient Judaism}

As the quotation from Sirach at the beginning of this article illustrates, the traditional, sacred and folk approaches to healing and the newer, secular and professional approaches to healing were in conflict, with the latter slowly gaining ground. Most people probably sought help for their illnesses from folk healers and spiritual direction from priests and community religious leaders. Illness was also culturally and religiously defined as the result of $\sin$. It was assumed that forgiveness was required. Physical symptoms were the result of a direct cause, whether divine punishment or demon possession. In many cases illness brought shame, pollution or uncleanness, and therefore ostracism or marginalisation from family and society. In Matthew, the demoniacs lived in tombs, and the hemorrhaging woman would have been forbidden to marry, have sexual relations, or participate in religious activities. The leper was required to show himself to the priest and offer the proper sacrifices in order to re-enter society.

Healing was also understood as regaining wholeness or shalom: physical and spiritual wellbeing. Today we might ask what rites, ceremonies, or celebrations could help in formalising a person's full recovery and acceptance back into their place in their family, work, and communities (secular and faith communities), whether their illness be cancer, drug addiction, or psychiatric?

In Part 2, we will apply this approach to the healing stories in Matthew 8-9. 


\section{Acknowledgements}

\section{Competing interests}

The author declares that he has no financial or personal relationships which may have inappropriately influenced him in writing this article.

\section{References}

Allison, D.C., Jr., 1993, The new Moses: A Matthean typology, Wipf \& Stock, Eugene. Anderson, J.C., 1994, Matthew's narrative web: Over, and over, and over again Sheffield Academic Press, Sheffield. (Journal for the Study of the New Testament Supplement Series, 91).

Borg, M.J.\& Wright, N.T., 1999, The meaning of Jesus: Two visions, HarperSanFrancisco, New York.

Boring, M.E., Berger, K. \& Colpe, C. (ed.), 1995, Hellenistic commentary to the New Testament, Abingdon, Nashville.

Bruner, J. \& Feldman, C.F., 1996, 'Group narrative as a cultural context of autobiography', in D.C. Rubin (ed.), Remembering our past: Studies in autobiographical memory, pp. 291-317, Cambridge University Press, Cambridge.

Cobb, B., 1958, 'Why do people return to quacks?' in E.G. Jaco (ed.), Patients, physicians and illness, pp. 283-287, Free Press, New York.

Culpepper, R.A., 2013a, 'Contours of the historical Jesus', in J G. van der Watt, (ed.), The quest for the real Jesus: Radboud prestige lectures by prof. Dr. Michael Wolter, pp. 67-85, Brill, Leiden. (Biblical interpretation series, 120).

Culpepper, R.A., 2013b, 'The weave of the tapestry: Character and theme in John', in C.W. Skinner, (ed.), Characters and characterization in the Gospel of John, pp. 18-35, Bloomsbury, London. (Library of New Testament Studies, 461).

Culpepper, R.A., 2015, 'Fulfilment of Scripture and Jesus' teachings in Matthew', In die Skriflig 49(2), Art. \#1986, 8 pages. (http://dx.doi.org/10.4102/ids.v49i2.1986).

Danby, H. (trans.), 1933, The Mishnah, Oxford University Press, Oxford.

Fabrega, Horacio, Jr., 1971, 'Medical anthropology', Biennial review of anthropology 7, 167-229.

Fiffer, E., 2014, 'There's no place like om', Luxury Magazine 2, 202-205.

Foster, G.M. \& Anderson, B., 1978, Medical anthropology, Wiley, New York.

Good, B.J., 1994, Medicine, rationality, and experience: An anthropological perspective, Cambridge University Press, Cambridge.

Hogan, L.P., 1992, Healing in the Second Temple Period, Vandenhoeck \& Ruprecht, Göttingen.

Kee, H.C., 1986, Medicine, miracle and magic in New Testament times, Cambridge University Press, Cambridge. (Society for New Testament studies monograph series, 55).

Kee, H.C., 1992, 'Medicine and healing', in N.D. Freedman (ed.), Anchor bible dictionary, vol. 4, pp. 659-664, Doubleday, New York.

Keener, C.S., 2010, 'Cultural comparisons for healing and exorcism narratives in Matthew's Gospel', HTS Teologiese Studies/Theological studies 6(1), Art. \#808, http://dx.doi.org/10.4102/hts.v66i1.808

Kingsbury, J.D., 1986, Matthew as story, Fortress, Philadelphia.
Malina, B.J. \& Rohrbaugh, R.L., 1992, Social science commentary on the synoptic Gospels, Fortress, Minneapolis.

Mattingly, C. \& Garro, L.C., 2000, Narrative and the cultural construction of illness and healing, University of California Press, Berkeley.

Meier, J.P., 1994, A marginal Jew: Rethinking the historical Jesus, vol. 2: Mentor, message, and miracles, Doubleday, New York.

Moore, S.D., 1989, Literary criticism and the Gospels: The theoretical challenge, Yale University Press, New Haven.

Morgan, L.M., 1990, 'The medicalization of anthropology: A critical perspective on the critical-clinical debate', Social Science \& Medicine 30(9), 945-950.

Pilch, J.J., 2000, Healing in the New Testament: Insights from medical and Mediterranean anthropology, Fortress, Minneapolis.

Powell, M.A., 1990, What is narrative criticism?, Fortress, Minneapolis. (Guides to biblical scholarship).

Raphael, R., 2010, 'Healing', in J.J. Collins \& D.C. Harlow (eds.), The Eerdmans dictionary of early Judaism, pp. 709-711, Eerdmans, Grand Rapids.

Sansom, B., 1982, 'The sick who do not speak', in D. Parkin (ed.), Semantic anthropology, pp. 183-195, Academic Press, London.

Scheper-Hughes, N., 1979, Saints, scholars, and schizophrenics: Mental illness in rural Ireland, University of California Press, Berkeley.

Scheper-Hughes, N., 1989, 'Three propositions for a critically applied medical anthropology', in Kroeber Anthropological Society Papers 69-70, 62-77.

Scheper-Hughes, N. \& Lock, M.M., 1986, 'Speaking "truth" to illness: Metaphors, reification, and a pedagogy for patients', Medical Anthropology Quarterly 17, 137-140.

Scheper-Hughes, N. \& Lock, M.M., 1987, 'The mindful body: A prolegomenon to future work in medical anthropology', Medical Anthropology Quarterly (n.s.) 1, 6-41.

Singer, M., 1989, 'The coming of age of critical medical anthropology', Social science \& Medicine 28, 1193-1203.

Singer, M., 1990, 'Reinventing medical anthropology: Toward a critical realignment', Social science \& Medicine 30(2), 179-187.

Sontag, S., 1977, Illness as metaphor and AIDS and its metaphors, Farrar, Straus \& Giroux, New York.

Spencer, F.S., 2010, 'Scripture, hermeneutics, and Matthew's Jesus', Interpretation 64, 368-378.

Strauss, E., 1966, 'Upright posture', in E. Strauss, Phenomenological psychology: The selected papers of Erwin Strauss, pp. 137-165, Basic Books, New York.

Talbert, C.H., 2010, Matthew, Baker Academic, Grand Rapids. (Paideia Commentaries on the New Testament).

Temkin, O., 1991, Hippocrates in a world of pagans and Christians, Johns Hopkins University Press, Baltimore.

Van der Watt, J.G. \& Zimmermann, R. (eds.), 2012, Rethinking the ethics of John: 'Implicit ethics' in the Johannine writings, Mohr Siebeck, Tübingen. (Kontexte und Normen neutestamentlicher Ethik/Contexts and Norms of New Testament Ethics, 3).

Wilkinson, J., 1998, The Bible and healing: A medical and theological commentary, Handsel Press, Edinburgh.

Wilson, W.T., 2014, Healing in the Gospel of Matthew: Reflections on method and ministry, Fortress, Minneapolis.

World Health Organization, 1948, Official Records of the World Health Organization no. 2, p. 100, viewed 26 Oct. 2016, from http://www.who.int/about/mission/en

Young, A., 1995, The harmony of illness, Princeton University Press, Princeton. 